\title{
Unbowed respect for tradition saves countless initiates' lives
}

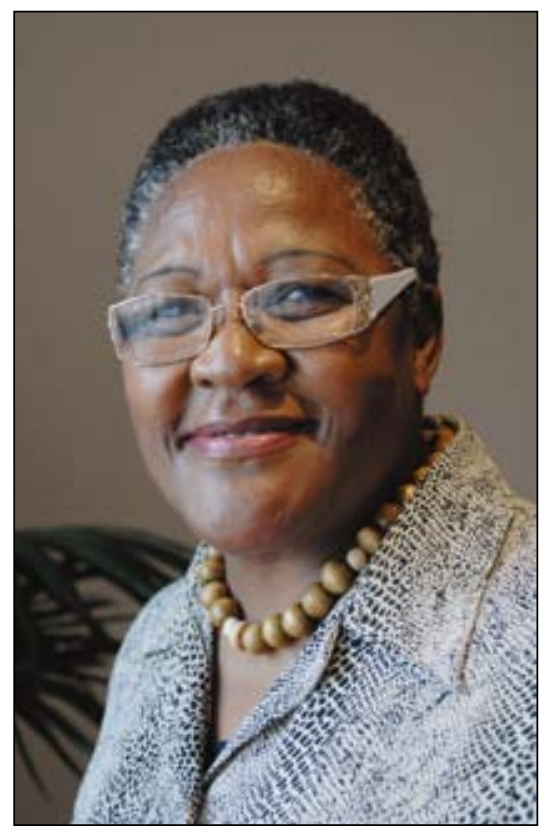

Dr Elizabeth-Mamisa Chabula-Nxiweni, Port Elizabeth's Municipal Health Chief and safecircumcision activist

Picture: Ivor Markman, Eastern Province Herald.

A protracted and lonely campaign for safe male circumcision in the traditional, maledominated rural Eastern Cape is finally saving multiple lives - its chief protagonist a medical doctor and mother of 10 who is now Port Elizabeth's Municipal Health Chief.

Dr Elizabeth-Mamisa Chabula-Nxiweni, 64 , is a one-woman phenomenon. She graduated top of her medical school class, gave birth to the last 2 of her 10 offspring while studying, pioneered institutionalised safe circumcision training among local traditional surgeons and created the Emmanuel Haven, a 175-person HIV/AIDS day care facility and crèche in Motherwell. The Haven, soon to be a 100-bed step-down facility, is also a government-accredited ARV site, catering to 2000 outpatients, and boasts a community 'awareness' radio station, eye clinic and a 1.65 hectare hydroponics vegetable garden - all initiated by ChabulaNxiweni.

The municipal health chief, who doubles as a Presbyterian minister, is no stranger to the fast-moving rough and tumble of South African politics where, as a former ANC activist with political prisoner family, she has more than held her own. Two years ago, when listed by the now embattled
COPE for national parliament, her ANC-led municipality promptly sacked her, citing imbedded conflict of interest legislation. She took them to the High Court and won, reoccupying her Public Health Executive Director seat which she still holds today, plus recouping 2 months of illegally withheld salary.

\section{It's her uncompromising belief that 'the truth will always win' that enabled her to engage, battle with and/or win over a formidable array of traditional surgeons for whom culture and traditional gender roles were non-negotiable.}

\section{'The truth will always win'}

It's her uncompromising belief that 'the truth will always win' that enabled her to engage, battle with and/or win over a formidable array of traditional surgeons for whom culture and traditional gender roles were non-negotiable.

'I would tell them there's nothing wrong with custom but children are dying, there's HIV, bleeding, using the same instruments, doing it too fast - and (the self-interest dealsealer) you can have an open lesion and get blood splashed on you,' she told Izindaba. The last snippet of information usually got the attention of the most hardened traditionalists, she chuckles.

Yet it was a mixture of persuasion, deep respect for cultural and gender practices and her calling to alleviate human suffering that gradually began making a difference in Motherwell, where she set up private practice in 1988 after graduating from MEDUNSA and completing her internship in Umtata. The pivotal event was a visit by four fathers to her practice during that year's December (holidays) initiation season. Her youngest brother, David, freshly released from political prison, told her he suspected they were the fathers of young, seriously ill initiates. 'I refused to see them because I knew that if it came out that they'd seen a (medical) doctor, let alone a woman, they would be immediate outcasts.'

\section{First/Third-World irony}

But in one of those strange First/Third-World ironies, the men immediately threatened to take her to the Medical and Dental Council for refusing treatment of patients. She relented, returning to her surgery under cover of darkness to treat the boys.

'I was shocked. One boy was dehydrated, one had a gangrenous penis, another sepsis ... they had used potato peels, coals and brown paper and (mistakenly non-medicinal) leaves as wound dressings.'

Six months passed before the next batch of boys came in and she could 'no longer ignore' what was obviously a serious and an ongoing societal malady. Dr Chabula-Nxiweni was the health desk incumbent on the local, maledominated and ANC-aligned Motherwell Community Development Forum and that very week secured their grudging permission to begin talking to local iNgcibisi (traditional surgeons) and amaKhankatha (traditional (male) nurses). (Traditional nurses accompany new initiates as health care minders during their bush retreat.)

By 1991 the 'Motherwell Traditional Surgeons Attendance Association' was formed after traditional surgeons and nurses had begun meeting in growing numbers at Dr Chabula-Nxiweni's surgery or the local clinic every Sunday for almost 2 years.

\section{She spoke on the link}

between HIV and traditional circumcision, little knowing then about the $60 \%$ preventive efficacy of a properly controlled and managed surgical snip.

\section{Traditional surgeons derided by their peers}

Her opponents dubbed these 'sell outs' Imncibisi zomNxiweni or the Surgeons of Nxiweni - a derogatory term centering on their being led by a female. Among the early standard operating procedures she introduced were 'obligatory' postcircumcision medical check-ups and parents or guardians signing permission for traditional circumcision (parents often found themselves financially beholden to the traditional practitioners at the then prices of R80 for surgery and R120 for the nurse). Dr Chabula-Nxiweni's efforts received global attention when she was invited to make a presentation at a conference on traditional circumcision held in Washington DC in 2002. She spoke on the link between HIV and traditional circumcision, little knowing then about the $60 \%$ preventive efficacy of a properly controlled and managed surgical snip. 
The funding began to flow. Showing great tactical nous, she persuaded USAID to donate via MEDUNSA, the SA Research Institute to inject funding via the University of Port Elizabeth, and various other funders to work via her Alma Mater. 'I gave them all my material and they replicated my work. I wasn't documenting and researching, she explained, adding that this also avoided any financial misappropriation/mismanagement landmines.

Her culturally and traditionally sensitive engagement protocols (her father, a Malawian, was a traditional healer and, for example, only male doctors do 'bush visits' of initiates) became widely used as each institution devised training academies for traditional practitioners. She's particularly proud that since 1991 there has not been a single recorded death or botched circumcision in the Motherwell area.

\section{A 'thank you present' for educating her kids}

A single mother (she was divorced early on in her marriage and raised and educated her 10 children on her own), she is now chairperson of the Emmanuel Haven Board which employs over 400 caregivers, homebased carers, gardeners and radio station staffers.

'The personal spiritual gain from the Haven is much higher than any money. I've achieved what I wanted to, which is to say thank you to the community of Motherwell for supporting me in my practice for 20 years and getting my kids educated.'

\section{I've achieved what I wanted to,} which is to say thank you to the community of Motherwell for supporting me in my practice for 20 years and getting my kids educated.'

Four of her children are medical doctors (one due to write his orthopaedic exams this year), 3 are chartered accountants, another is close to becoming an actuary, one has just completed his BComm and another is an industrial engineer. How did she do it? 'I attribute it to God, a good gene mix and laying solid foundations and value systems in the home. I was firm but not cruel to my kids and laid down the terms of reference clearly; my job was to provide a home and food and pay for their education and their reciprocal job was to read their books and pass.'

As for safe male circumcision and proper wound management, it has done more good than she ever believed possible. 'In this big sea of medical intervention and knowledge I have one drop and that to me is very satisfying. I don't even want to be recognised but I recognise myself for me - I have that one drop.' The ripples from that drop continue to save and change lives daily - recognised in a slew of awards locally and internationally. These include the Health category for the Nelson Mandela Municipality at the 2007 World Leadership Awards (Emmanuel Haven), the Impumelelo Innovation Trust Award (Emmanuel Haven) and SABC 2's Tribute Achiever Award in August last year for wound management during traditional circumcision.

Some drop indeed.

\section{Chris Bateman}

